\title{
A Comparative Study on Exergetic Performance Assessment for Drying of Broccoli Florets in Three Different Drying Systems
}

\author{
Filiz Icier , Neslihan Colak , Zafer Erbay , Ebru Hancioglu Kuzgunkaya \& Arif \\ Hepbasli
}

To cite this article: Filiz Icier , Neslihan Colak , Zafer Erbay , Ebru Hancioglu Kuzgunkaya \& Arif Hepbasli (2010) A Comparative Study on Exergetic Performance Assessment for Drying of Broccoli Florets in Three Different Drying Systems, Drying Technology, 28:2, 193-204, DOI: 10.1080/07373930903524017

To link to this article: http://dx.doi.org/10.1080/07373930903524017

\section{曲 Published online: 08 Mar 2010.}

Submit your article to this journal ¿

Џ Article views: 225

Q View related articles $\longleftarrow$

4 Citing articles: 21 View citing articles $\asymp$ 


\title{
A Comparative Study on Exergetic Performance Assessment for Drying of Broccoli Florets in Three Different Drying Systems
}

\author{
Filiz Icier, ${ }^{1}$ Neslihan Colak, ${ }^{2}$ Zafer Erbay, ${ }^{1}$ Ebru Hancioglu Kuzgunkaya, ${ }^{3}$ and \\ Arif Hepbasli ${ }^{4}$ \\ ${ }^{1}$ Department of Food Engineering, Faculty of Engineering, Ege University, Izmir, Turkey \\ ${ }^{2}$ Department of Food Engineering, Faculty of Engineering, Pamukkale University, Denizli, Turkey \\ ${ }^{3}$ Geothermal Energy Research and Application Center, Izmir Institute of Technology, Izmir, Turkey \\ ${ }^{4}$ Department of Mechanical Engineering, Faculty of Engineering, Ege University, Izmir, Turkey
}

\begin{abstract}
This article deals with the exergy analysis and evaluation of broccoli in three different drying systems. The effects of drying air temperature on the exergy destruction, exergy efficiency, and exergetic improvement potential of the drying process were investigated. The exergy destruction rate for the drying chamber increased with the rise in the drying air temperature at $1.5 \mathrm{~m} / \mathrm{s}$, both in the tray and the heat pump dryer. The highest exergy efficiency value was obtained as $90.86 \%$ in the fluid bed dryer in comparison to the other two drying systems and the improvement potential rate was the highest in the heat pump dryer during drying of broccoli at the drying air temperature of $45^{\circ} \mathrm{C}$ and the drying air velocity of $1.0 \mathrm{~m} / \mathrm{s}$.
\end{abstract}

Keywords Exergy analysis; Exergy performance; Fluidized bed dryer; Heat pump dryer

\section{INTRODUCTION}

Large quantities of food products are dried to improve shelf life, reduce packing costs, lower shipping weights, enhance appearance, encapsulate original flavor, and maintain nutritional value. In this regard, the goals of drying process research in the food industry may be classified in three groups as follows: (a) economic considerations, (b) environmental concerns, and (c) product quality aspects. ${ }^{[1]}$

Broccoli (Brassica oleracea) is a floral vegetable rich in vitamins $\mathrm{A}$ and $\mathrm{C}$, isothiocyanine, and especially glucoraphanin and its derivative sulforaphane. Health-conscious consumers have an increasing demand for young seedlings and florets of broccoli to prevent breast cancer. ${ }^{[2]}$ Particularly, the occurrence of anticancer principles in broccoli (or Brassica oleracea) has been reported ${ }^{[3-5]}$ Fahey et al. ${ }^{[6]}$ reported the presence of a significant level of phase 2

Arif Hepbasli is also Visiting Professor, King Saud University, Riyadh, Saudi Arabia.

Correspondence: Filiz Icier, Department of Food Engineering, Faculty of Engineering, Ege University, 35100 Izmir, Turkey; E-mail: filiz.icier@ege.edu.tr activities among different samples of fresh broccoli, which offer protective mechanism in carcinogenesis. Broccoli is a rich source of phytomolecules such as sulphoraphane, indoles, isothiocynates, etc. ${ }^{[7]}$ Broccoli dehydration has not been investigated to a great extent and few data are available in the literature. ${ }^{[8-12]}$

The various kinds of energy display different qualities; these differences manifest themselves in their ability to feed and drive energy processes and their ability to be converted into other kinds of energy. As indicated by Szargut et al., ${ }^{[30]}$ the capacity for doing work refers to a measure of the quality of energy. This fact is clarified by Dincer ${ }^{[31]}$ as

\footnotetext{
high quality (or high temperature) energy sources such as fossil fuels are used for relatively low temperature processes like water and space heating or cooling, industrial drying, industrial steam production, etc. and hence resulting in much lower exergy efficiencies. In this regard, exergy efficiency permits a better matching of energy sources and uses, leading to that high quality energy must be used for performing high-quality work.
}

Finally, drying is a low-temperature process. In this regard, the drying systems with higher exergy efficiencies and lower improvement potentials should be selected at the design stage.

In evaluation of the performance of food systems, energy analysis method has been widely used, whereas studies on exergy analysis, especially on exergetic assessment of drying process, are relatively few in number. ${ }^{[13-17]} \mathrm{In}$ these previous studies, the drying process was thermodynamically modeled by Dincer and Sahin ${ }^{[14]}$ and drying of different products such as wheat kernel, ${ }^{[18]}$ pistachio, ${ }^{[13]}$ red pepper slices, ${ }^{[15]}$ potato, ${ }^{[16,19]}$ apple slices, ${ }^{[20]}$ pumpkin, ${ }^{[17]}$ laurel leaves, ${ }^{[21,22]}$ pasta, ${ }^{[23]}$ green olive, ${ }^{[24]}$ and mint, ${ }^{[25]}$ was evaluated in terms of energetic and exergetic aspects using various drying devices, such as fluidized bed dryers, solar drying cabinets, cyclone-type dryers, 
convective-type hot air dryers, and heat pump dryers. In addition, other exergetic studies on drying also included a solar greenhouse, ${ }^{[26]}$ a freeze-drying process, ${ }^{[27]}$ a detailed review, ${ }^{[28]}$ and mathematical modeling. ${ }^{[29]}$

The present study differs from the previously conducted ones as follows: The main objective of this contribution is to perform exergy analyses of three drying processes in terms of drying of broccoli under different operating conditions and drying systems for the assessment of the drying performance and to compare them with each other.

\section{MATERIALS AND PROCEDURE Material}

Fresh broccoli (Brassica oleracea) was purchased from a local market in Izmir. It was processed within $24 \mathrm{~h}$. Broccoli samples were washed with water, and then the excess water on the surface of broccoli was removed with filter paper. Afterwards, florets of broccoli were separated. The average diameter of broccoli florets was $1.2 \mathrm{~cm}$ with a sphericity of 0.85 .

\section{Experimental Setup}

Broccoli was dried in the three different drying systems: in a laboratory-type tray dryer (Armfield UOP8, Hampshire, UK) shown schematically in Fig. 1, in a laboratory-type fluid bed dryer (Sherwood Scientific, Cambridge, UK) indicated schematically in Fig. 2, and in an air source heat pump conveyor dryer designed and constructed in the Department of Mechanical Engineering, Faculty of Engineering, Ege University, Izmir, Turkey, which is illustrated schematically in Fig. 3.

In the tray dryer, the drying air velocity was adjusted by an axial flow fan and fan speed control unit. The air was heated with an electric $3 \mathrm{~kW}$ heater placed inside the duct and air temperature was controlled by a heater power control unit. Drying compartment dimensions were $0.3 \mathrm{~m} \times 0.3 \mathrm{~m} \times 0.4 \mathrm{~m}$. The dryer included four sample trays.

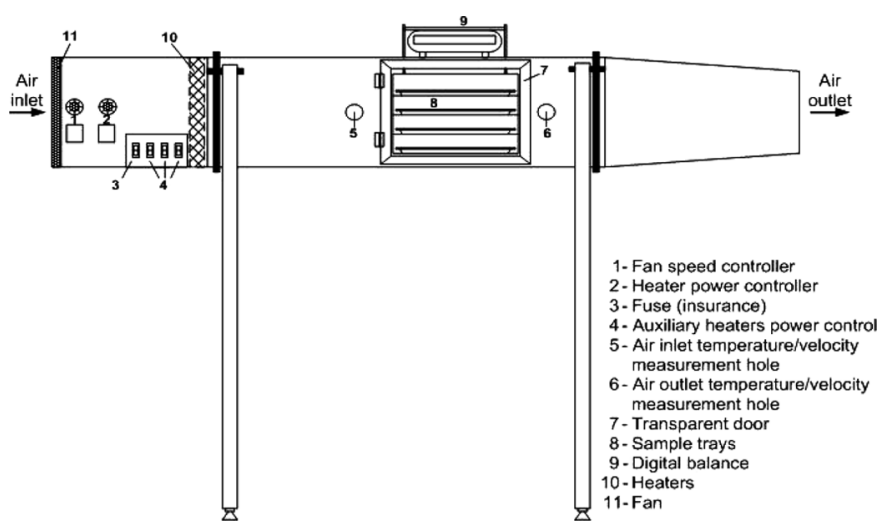

FIG. 1. Schematic illustration of the tray dryer.

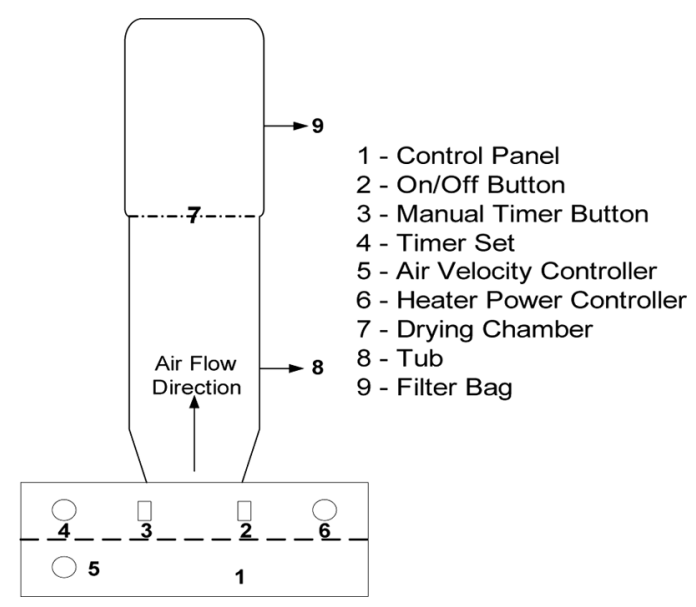

FIG. 2. Schematic illustration of the fluid bed dryer.

In the fluid bed dryer, the air was drawn through a mesh filter in the base of the cabinet and blown by a centrifugal fan over a $2 \mathrm{~kW}$ finned electrical heater. It flowed through stainless steel filter gauze before being delivered to the distributor gauze at the base of the dryer body. This distributed the air uniformly to the bed and also supported it. The air blower was controlled by a thyristor circuit to give a smooth vibration over a wide range of motor speeds and fine control of the drying temperature. The tub unit locked into position on the cabinet top by a simple bayonet fitting. A filter bag was employed to retain any stray particles of the sample being fluidized while allowing the passage of exit gases.

In the heat pump conveyor dryer, thedrying system consists of two main parts: (a) a heat pump and (b) a drying chamber. The air was heated by the heat pump system, which included a scroll compressor, two condensers (an internal and an external ones), an expansion valve, an

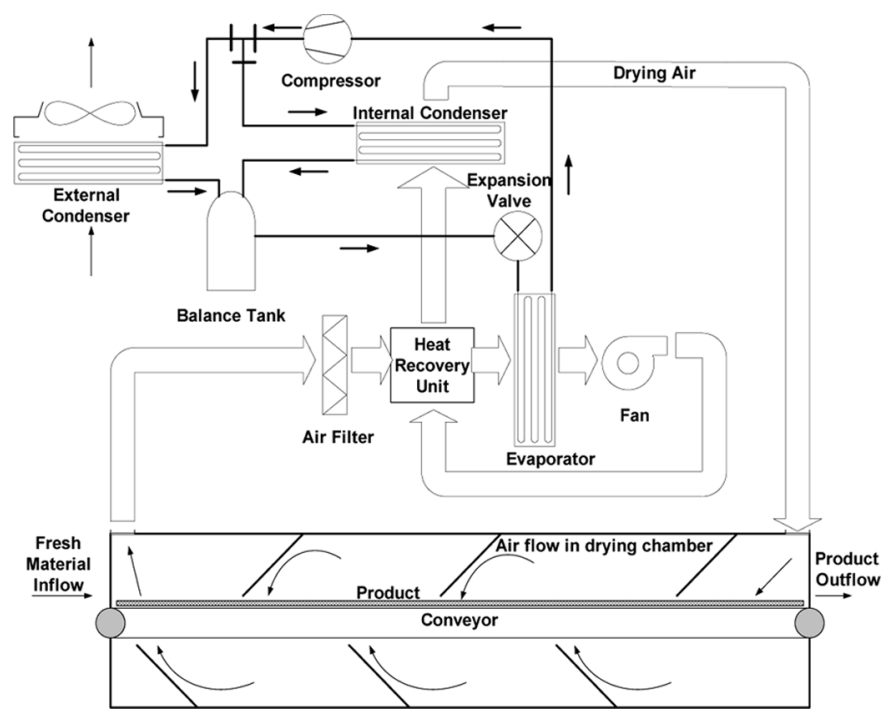

FIG. 3. Schematic illustration of the heat pump dryer. 
evaporator, and a heat recovery unit. Air temperature was controlled by a control unit, and $\mathrm{R} 407 \mathrm{C}$ was used as refrigerant in the heat pump system. The drying air velocity was regulated by a fan and fan speed control unit, and drying air was recycled. The drying compartment dimensions were $3 \mathrm{~m} \times 1 \mathrm{~m} \times 1 \mathrm{~m}$ and the drying material was moved by a conveyor band system worked by a motor.

\section{Drying Procedure and Measurements}

Broccoli florets were spread onto the trays as a thin layer and drying experiments were carried out at drying air velocities of $0.5,1.0$, or $1.5 \mathrm{~m} / \mathrm{s}$ in the tray dryer. In the fluid bed dryer, the drying air velocities were chosen as 1.7 and $2.7 \mathrm{~m} / \mathrm{s}$. Drying temperatures were 50,60 , or $70^{\circ} \mathrm{C}$ for both dryers. In the heat pump dryer, the drying air velocities were chosen as $0.5,1.0$, or $1.5 \mathrm{~m} / \mathrm{s}$ and drying air temperatures were set at 45,50 , or $55^{\circ} \mathrm{C}$. The drying air temperatures mentioned in the text were the mean dry bulb air temperatures, which were constant in the drying cabinet during drying.

Moisture loss was recorded at 5-min intervals during the drying process for obtaining drying curves. The sample moisture content was determined with a vacuum-oven method. ${ }^{[32]}$ The initial moisture content of the broccoli florets samples was determined to be $87 \%$ on a wet basis. The protein, ash, oil, carbohydrate, and fiber contents of the broccoli florets were determined. ${ }^{[33-36]}$ The composition of broccoli florets used in this study is given in Table 1. The broccoli florets were dried to the final moisture content of $8 \%$ because the equilibrium moisture content was taken as $8 \%$ for all drying conditions. The change of dimensionless moisture ratio (MR) during drying was calculated as $M R=\frac{M_{t}-M_{e}}{M_{\text {initial }}-M_{e}}$.

Humidities, temperatures, and velocities were measured with robust humidity probes (Testo, 0636.2140, Freiburg, Germany), vane/temperature probes (Testo, 0635.9540, Freiburg, Germany), and aprofessional telescopic handle for plug-in vane probes (Testo, 0430.0941, Freiburg, Germany), respectively. Measurements of drying air temperature, velocity, and relative humidity were recorded at inlet and outlet holes at every $10 \mathrm{~min}$ for the tray dryer

TABLE 1

Composition of broccoli florets

\begin{tabular}{lc}
\hline Component & Amount (\%) \\
\hline Water & 86.44 \\
Protein & 2.91 \\
Oil & 0.38 \\
Carbohydrate & 6.69 \\
Fibre & 2.68 \\
Ash & 0.90 \\
\hline
\end{tabular}

and $5 \mathrm{~min}$ for the fluid bed dryer. The surface temperature of the equipment was measured with a digital multimeter (Metex ME-32, Seoul, Korea) and the surface temperature of broccoli florets during drying was measured with an infrared thermometer with laser sighting (Testo 525-T2, Freiburg, Germany). A digital balance (Scaltec SBA 61, Goettingen, Germany) was used to measure the weight loss of sample during drying experiments. The ambient temperature and the relative humidity were observed and recorded with a multifunction instrument (Testo 350-XL/ 454, Control unit, Freiburg, Germany). The relative humidity of the air was also measured at the inlet and outlet of the dryer, and they were taken into account in calculations.

\section{Experimental Uncertainty}

Uncertainty analysis is needed to prove the accuracy of the experiments. Errors and uncertainties in the experiments can arise from the instrument selection, condition, calibration, environment, observation and reading, and test planning. ${ }^{[37]}$ An uncertainty analysis was performed using the method described by Holman: ${ }^{[38]}$

$$
U_{F}=\left[\left(\frac{\partial F}{\partial z_{1}} u_{1}\right)^{2}+\left(\frac{\partial F}{\partial z_{2}} u_{2}\right)^{2}+\cdots+\left(\frac{\partial F}{\partial z_{n}} u_{n}\right)^{2}\right]^{1 / 2}
$$

\section{ANALYSIS \\ Mass Balance Equation}

The mass balance equation can be expressed in the rate form as

$$
\sum \dot{m}_{i n}=\sum \dot{m}_{o u t}
$$

where $\dot{m}$ is the mass flow rate, and the subscript in stands for inlet and out for outlet.

\section{Energy Balance Equations}

Balance equations were applied for a general steadystate, steady-flow process to find the work and heat interactions, the rate of exergy decrease, the rate of irreversibility, and the energy and exergy efficiencies. ${ }^{[39,40]}$

The general energy balance was written as

$$
\sum \dot{E}_{\text {in }}=\sum \dot{E}_{\text {out }} \quad \text { or } \quad \dot{Q}+\sum \dot{m}_{\text {in }} \dot{h}_{\text {in }}=\dot{W}+\sum \dot{m}_{\text {out }} \dot{h}_{\text {out }}
$$

where $\dot{m}$ is the mass flow rate and the subscripts in and out stand for inlet and outlet, respectively. $\dot{E}_{i n}$ is the rate of net energy transfer in, $\dot{E}_{\text {out }}$ is the rate of net energy transfer out by heat, work, and mass. $\dot{Q}=\dot{Q}_{n e t, i n}=\dot{Q}_{i n}-\dot{Q}_{\text {out }}$ is the rate of net heat input, $\dot{W}=\dot{W}_{\text {net,out }}=\dot{W}_{\text {out }}-\dot{W}_{\text {in }}$ is the rate of net work output, and $h$ is the enthalpy per unit mass. 


\section{Exergy Balance and Exergy Improvement Potential Equations}

The general exergy balance was expressed in the rate form as

$$
\begin{aligned}
& \sum \dot{E} x_{\text {in }}-\sum \dot{E} x_{\text {out }}=\sum \dot{E} x_{d e s t} \text { or } \\
& \sum\left(1-\frac{T_{0}}{T_{s}}\right) \dot{Q}_{\text {loss }}-\dot{W}+\sum \dot{m}_{\text {in }} \psi-\sum \dot{m}_{\text {out }} \psi=\dot{E} x_{\text {dest }}
\end{aligned}
$$

$$
\psi=\left(h-h_{0}\right)-T_{0}\left(s-s_{0}\right)
$$

where $\dot{Q}_{\text {loss }}$ is the heat transfer rate through the boundary at temperature $T_{s}$ at location $s, \dot{W}$ is the work rate, $\psi$ is the flow (or specific) exergy, $s$ is the specific entropy, and the subscript 0 indicates properties at the dead state of $P_{0}$ and $T_{0} \cdot{ }^{[41]}$

The exergy destroyed or the irreversibility was expressed as follows:

$$
I=\dot{E} x_{d e s t}=T_{0} \dot{S}_{g e n}
$$

where $\dot{S}_{g e n}$ is the rate of entropy.

Van Gool ${ }^{[42]}$ proposed that maximum improvement in the exergy efficiency for a process or system was obviously achieved when the exergy loss or irreversibility $\left(\dot{E} x_{i n}-\right.$ $\dot{E} x_{\text {out }}$ ) was minimized. Consequently, he suggested that it was useful to employ the concept of an exergetic improvement potential when analyzing different processes or sectors of the economy. This improvement potential in the rate form, denoted $I \dot{P}$, was given by: ${ }^{[43]}$

$$
I \dot{P}=(1-\eta)\left(\dot{E} x_{\text {in }}-\dot{E} x_{\text {out }}\right)
$$

$\eta$ is the exergy efficiency, which is explained in the section Exergy Efficiencies for Drying in detail.

\section{Determination of Thermal Properties of Broccoli Determination of Specific Heats}

The protein, fat, carbohydrate, ash, and fiber contents of broccoli were determined and used in the calculation of specific heat of broccoli samples: ${ }^{[44]}$

$$
\begin{aligned}
C_{p}= & C_{\text {prot }} X_{\text {prot }}+C_{\text {fat }} X_{\text {fat }}+C_{\text {carb }} X_{\text {carb }}+C_{a s h} X_{\text {ash }} \\
& +C_{\text {fibre }} X_{\text {fibre }}+C_{w} X_{w}
\end{aligned}
$$

\section{Determination of Specific Enthalpies}

The specific enthalpy of broccoli was written in terms of specific heat as ${ }^{[44]}$

$$
h=\sum h_{i} X_{i}=\sum \int_{T_{1}}^{T_{2}} C_{i} X_{i} d T
$$

where $h$ is the specific enthalpy of the individual food components and $X_{i}$ is the mass fraction of food components.
Assuming a constant $C$ over the temperature range, Eq. (9a) reduced to:

$$
h=\sum C_{i} X_{i}\left(T_{m}-T_{0}\right)
$$

where $T_{0}$ is the reference temperature, which was taken to be $0^{\circ} \mathrm{C}$ in this study; and $T_{m}$ is the temperature of food item in degrees Celsius. Equation (9b) was applied for the temperature range of $0-70^{\circ} \mathrm{C}$ in this study.

\section{Determination of Entropies}

The specific entropies of food were given by ${ }^{[45]}$

$$
\begin{gathered}
s_{m, \text { in }}-s_{m o}=C_{p_{m, \text { in }}} \ln \left(T_{m, \text { in }} / T_{o}\right) \\
s_{m, \text { out }}-s_{m o}=C_{p_{m, \text { out }}} \ln \left(T_{m, \text { out }} / T_{0}\right)
\end{gathered}
$$

where $T_{0}$ is the reference temperature, and $T_{m}$ is the temperature of food item in $\mathrm{K}$.

\section{Performing Exergy Analyses}

Total exergy inflow, outflow, and losses of the tray and the drying chamber were estimated based on the exergy analysis, which determined the exergy values at steadystate points and the reason for exergy variation for the process. A schematic illustration of the dryer systems is given in Figs. 1-3, and the exergy analysis was performed according to this scheme using the relations presented in this subsection: ${ }^{[15,45]}$

The enthalpy of drying air was

$$
h_{d a}=c_{P d a} T+\omega h_{s a t @ T}
$$

where $c_{P d a}$ defines the specific heat of drying air, $T$ is the drying air temperature, $\omega$ is the absolute humidity, and $h_{\text {sat@T }}$ is the enthalpy of the saturated vapor at the temperature $T$.

To evaluate the entropy of moist air, the contribution of each component in the mixture was determined at the mixture temperature and the partial pressure of the component:

$$
s_{d a}=s_{a}-R_{a} \ln \frac{P_{a}}{P_{0}}+w\left(s_{v}-R_{v} \ln \frac{P_{v}}{P_{0}}\right)
$$

The exergy balance equation for the dryer was

$$
\begin{aligned}
\dot{E} x_{m, \text { in }}- & \dot{E} x_{m, o u t}=\dot{E} x_{d a, \text { in }}-\dot{E} x_{d a, \text { out }}+\dot{E} x_{\text {evap }} \\
& -\dot{E} x_{\text {loss }}-\dot{E} x_{D}
\end{aligned}
$$

where $\dot{E} x_{m}$ is the exergy transfer rate of the material, $\dot{E} x_{d a}$ is the exergy transfer rate of the drying air, $\dot{E} x_{\text {evap }}$ is the exergy evaporation rate of the dryer, $\dot{E} x_{\text {loss }}$ is the rate of 
exergy loss the surrounding, and $\dot{E} x_{D}$ is the rate of exergy destruction in the dryer.

The specific exergies at inlets $\left(\psi_{m, \text { in }}\right)$ and outlets $\left(\psi_{m, \text { out }}\right)$ of the material are given by:

$$
\begin{gathered}
\psi_{m, \text { in }}=\left(h_{m, \text { in }}-h_{m, 0}\right)-T_{0}\left(s_{m, \text { in }}-s_{m, 0}\right) \\
\psi_{m, \text { out }}=\left(h_{m, \text { out }}-h_{m, 0}\right)-T_{0}\left(s_{m, \text { out }}-s_{m, 0}\right)
\end{gathered}
$$

The specific exergies with a stream of drying air entering and leaving the dryer were as follows:

$$
\begin{gathered}
\psi_{d a, \text { in }}=\left(h_{d a, i n}-h_{0}\right)-T_{0}\left(s_{d a, i n}-s_{d a, o}\right) \\
\psi_{d a, \text { in }}=\left(h_{d a, \text { out }}-h_{d a, o}\right)-T_{0}\left(s_{d a, o u t}-s_{d a, o}\right)
\end{gathered}
$$

where $\psi_{d a, \text { in }}$ and $\psi_{\text {da,out }}$ are the specific exergy transfers at inlets and outlets, respectively; $h_{0}, s_{0}$ denote the specific enthalpy and specific entropy at the temperature of dead state $\left(T_{0}\right)$, respectively; $h_{d a, i n}$ and $s_{d a, \text { in }}$ denote the specific enthalpy and the specific entropy at the temperature of drying air entering the dryer $\left(T_{d a, i n}\right)$, respectively; and $h_{d a, \text { out }}$ and $s_{d a, \text { out }}$ denote the specific enthalpy and the specific entropy of drying air at the temperature of the drying air exiting, respectively. The potential and kinetic exergies were negligible.

The heat transfer rate due to phase change was

$$
\dot{Q}_{\text {evap }}=\dot{m}_{w} \cdot h_{f g}
$$

The rate of exergy transfer due to evaporation of the dryer was as follows:

$$
\dot{E} x_{\text {evap }}=\left[1-\frac{T_{0}}{T_{m}}\right] \dot{Q}_{\text {evap }}
$$

Heat transfer rate to the environment was given by

$$
\dot{Q}_{\text {loss }}=\dot{Q}_{\text {evap }}-\dot{m}_{m}\left(h_{m, \text { out }}-h_{m, \text { in }}\right)+\dot{m}_{d a}\left(h_{d a, \text { in }}-h_{d a, \text { out }}\right)
$$

The following equation was used to calculate the rate of exergy loss to the surrounding, where $T_{S}$ is the surface temperature

$$
\dot{E} x_{L}=\left(1-\frac{T_{0}}{T_{s}}\right) \dot{Q}_{l o s s}
$$

\section{Exergy Efficiencies for Drying}

There are two ways of formulating exergetic efficiency for drying systems. ${ }^{[13,17,18,45]}$ The first one can be defined as the ratio of the product exergy to exergy inflow as follows: ${ }^{[13,17]}$

$$
\eta_{e x 1}=\frac{\text { Exergy inflow }- \text { Exergy loss }}{\text { Exergy inflow }}=1-\frac{\dot{E} x_{\text {loss }}}{\dot{E} x_{\text {in }}}
$$

The second may be defined on the product/fuel basis. The product is the rate of exergy evaporation and the fuel is the rate of exergy drying air entering the dryer chamber. In this regard, exergy efficiency may be written as follows: ${ }^{[18,45]}$

$$
\eta_{e x 2}=\frac{\dot{E} x_{e v a p}}{\dot{E} x_{d a}}
$$

In this study, the exergy efficiency values were calculated using Eq. (23a) and compared to those calculated by Eq. (23b) in the literature.

Equations were solved using Microsoft Excel. The thermodynamic properties of water and air were found using the Engineering Equation Solver software package. ${ }^{[46]}$

\section{RESULTS AND DISCUSSION}

The thermodynamic analyses of drying process of broccoli were carried out by using data from the experiments conducted at different drying air temperatures for each system. A detailed uncertainty analysis was performed for experimental measurements of parameters and total uncertainties of predicted values. Results of uncertainty analysis are listed in Table 2.

Figure 4 presents the typical variation of moisture content during drying at the constant drying air temperature as an example of $50^{\circ} \mathrm{C}$. The drying rate decreased continuously with the drying time (Fig. 4). Because there was no constant rate drying period in these curves, all the drying operations occurred in the falling rate period. Because the capacity, dimensions, and characteristic parameters for each drying system were different, the system parameters were as close as possible to each other to make the comparisons accurate. The exergy efficiency was compared at the constant drying air temperature of $50^{\circ} \mathrm{C}$, because it was the shared temperature for all systems used. However, the drying air velocity was $1.5 \mathrm{~m} / \mathrm{s}$ for the tray dryer and the heat pump dryer, whereas it was $1.7 \mathrm{~m} / \mathrm{s}$ for the fluid bed dryer, which was the lowest air velocity possible in the fluid bed dryer. Because the air velocity for the fluid bed dryer was higher than the others, the fast drying for this dryer could be due to the effect of velocity. The dryer efficiencies could not be compared by this plot (Fig. 4). The variations of the exergy efficiency values obtained from Eq. (23a), exergy destruction, and improvement potential rates with various drying air temperatures and velocities in different drying systems were investigated to make the comparison more accurate (Figs. 5 and 6).

The exergy efficiency in the tray dryer changed between 59.70 and $81.92 \%$ (Table 3). Maximum exergy efficiency in the tray dryer was obtained at a drying air of $60^{\circ} \mathrm{C}$ with an air velocity of $1.5 \mathrm{~m} / \mathrm{s}$. Similarly, the exergy efficiency of the fluid bed drying chamber varied between 74.23 and $90.86 \%$ (Table 3 ). In the heat pump dryer, exergy efficiencies altered between 75.59 and $88.66 \%$ (Table 3). The 
TABLE 2

Uncertainties of the experimental measurements and total uncertainties for predicted values

\begin{tabular}{lcl}
\hline Parameter & Unit & Comment \\
\hline $\begin{array}{l}\text { Experimental measurements } \\
\text { Uncertainty in the }\end{array}$ & ${ }^{\circ} \mathrm{C}$ & \pm 0.224 \\
$\begin{array}{l}\text { temperature measurement } \\
\text { Uncertainty in the weight }\end{array}$ & $\mathrm{g}$ & \pm 0.00051 \\
$\begin{array}{l}\text { measurement } \\
\text { Uncertainty in the air }\end{array}$ & $\mathrm{m} / \mathrm{s}$ & \pm 0.21 \\
$\begin{array}{l}\text { velocity measurement } \\
\text { Uncertainty in the }\end{array}$ & & \\
$\begin{array}{l}\text { measurement of relative } \\
\text { humidity of air }\end{array}$ & & \pm 0.41 \\
$\begin{array}{l}\text { Uncertainty in the } \\
\text { measurement of moisture }\end{array}$ & $\mathrm{g}$ & \pm 0.0016 \\
$\begin{array}{l}\text { content } \\
\text { Uncertainty in the pressure } \\
\text { measurement }\end{array}$ & $\mathrm{kPa}$ & $\pm 1.0 \%$ \\
$\begin{array}{l}\text { Uncertainty in the surface } \\
\text { temperature measurement }\end{array}$ & ${ }^{\circ} \mathrm{C}$ & \pm 1.0 \\
$\begin{array}{l}\text { Predicted values } \\
\text { Total uncertainty for MR }\end{array}$ & & \\
$\begin{array}{l}\text { Total uncertainty for } \eta \\
\text { Total uncertainty for } \dot{E} x_{d}\end{array}$ & Dimensionless & $\pm 2.48 \%{ }^{a}$ \\
Total uncertainty for IP & $\mathrm{kW}$ & $\pm 0.70 \%{ }^{c}$ \\
\hline
\end{tabular}

${ }^{a}$ Nominal value was taken as 0.030 .

${ }^{b}$ Nominal value was taken as 78.11 .

${ }^{c}$ Nominal value was taken as 0.061 .

${ }^{d}$ Nominal value was taken as 0.013 .

exergy efficiency decreased as the drying air temperature increased for the air velocity of 0.5 and $1.5 \mathrm{~m} / \mathrm{s}$, unlike $1.0 \mathrm{~m} / \mathrm{s}$ air velocity. The increasing air velocity in the

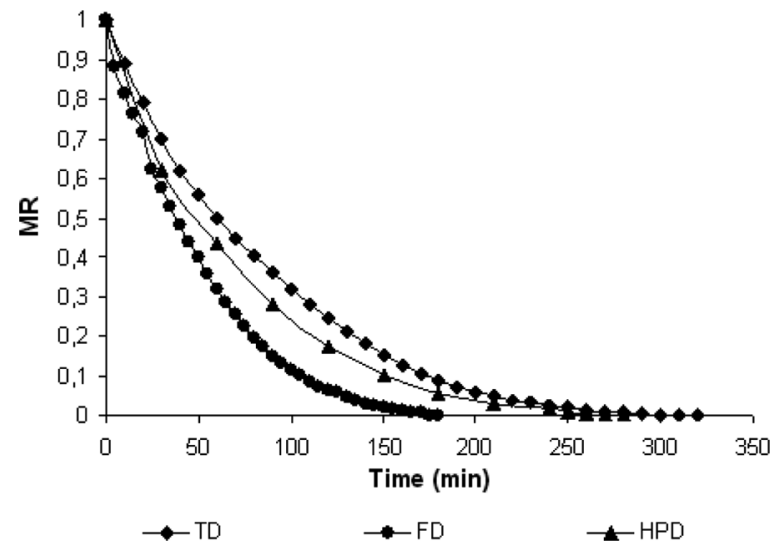

FIG. 4. Moisture content of broccoli during drying (drying air temperature: $50^{\circ} \mathrm{C}$, relative humidity: $13 \%$, air velocity: $1.5 \mathrm{~m} / \mathrm{s}$ for tray and heat pump dryer, $1.7 \mathrm{~m} / \mathrm{s}$ for fluid bed dryer).

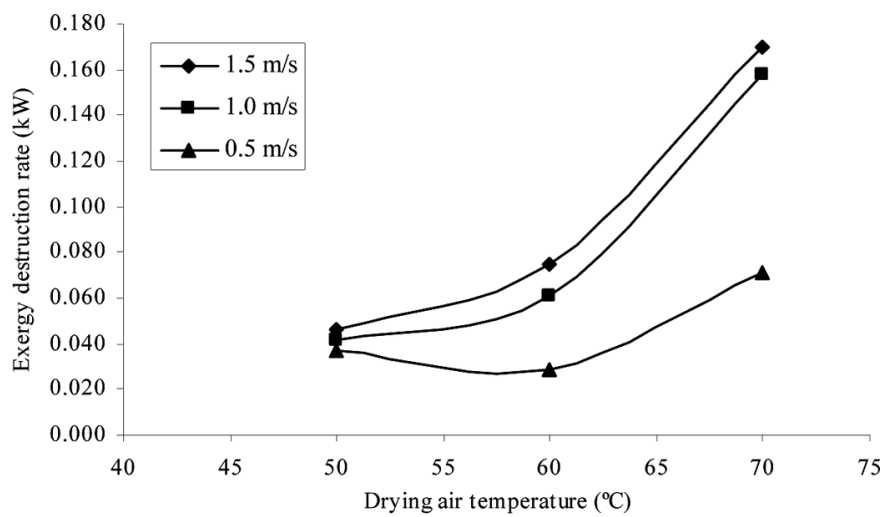

(a)

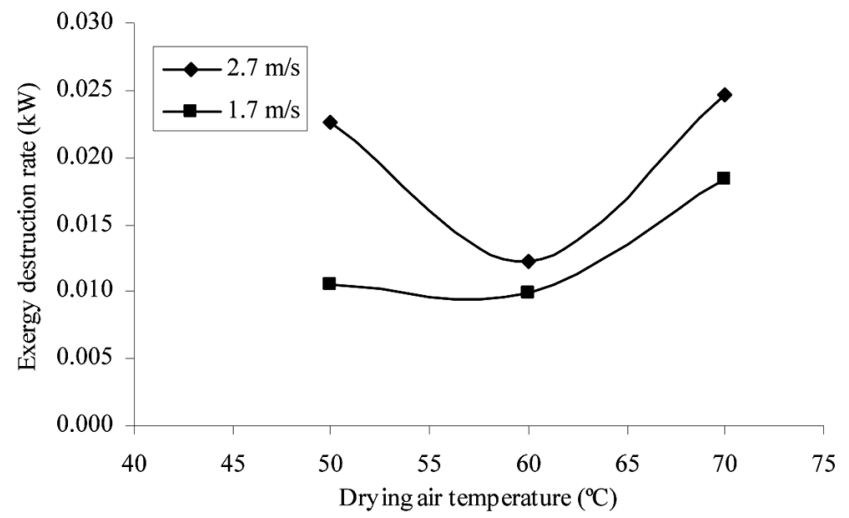

(b)

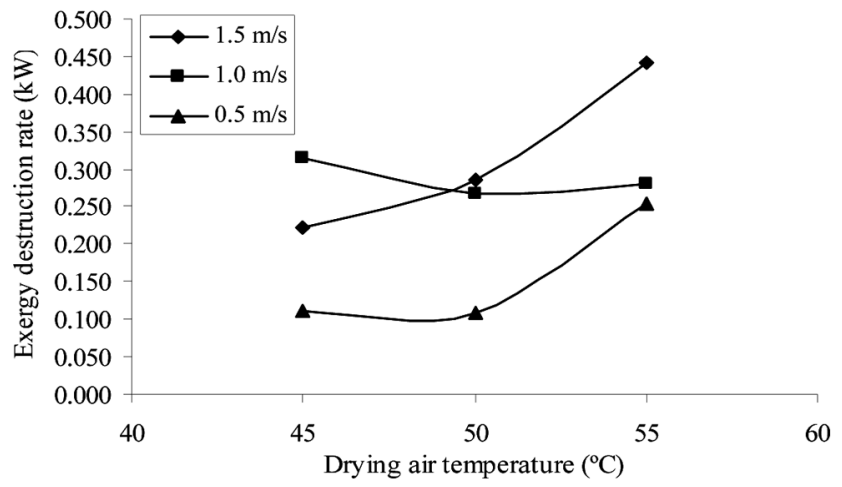

(c)

FIG. 5. The change of exergy destruction rate value with drying temperature during drying of broccoli florets in three different systems: (a) tray dryer, (b) fluid bed, and (c) heat pump.

drying system improved the exergy efficiencies in general. Interestingly, maximum exergy efficiencies in the fluid bed dryer and tray dryer were obtained at $60^{\circ} \mathrm{C}$. The highest value for all systems was $90.86 \%$, which was obtained at the drying air temperature of $60^{\circ} \mathrm{C}$ and velocity of $2.7 \mathrm{~m} / \mathrm{s}$ (highest air velocity) in the fluid bed dryer.

A comparison in exergy efficiency values for various products in the literature is given in Table 4. It is obvious from this table that the exergy efficiency values calculated 


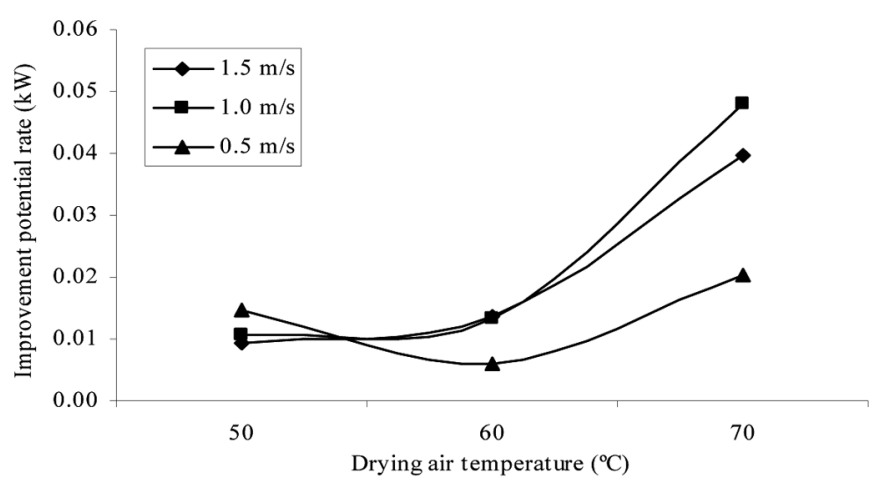

(a)

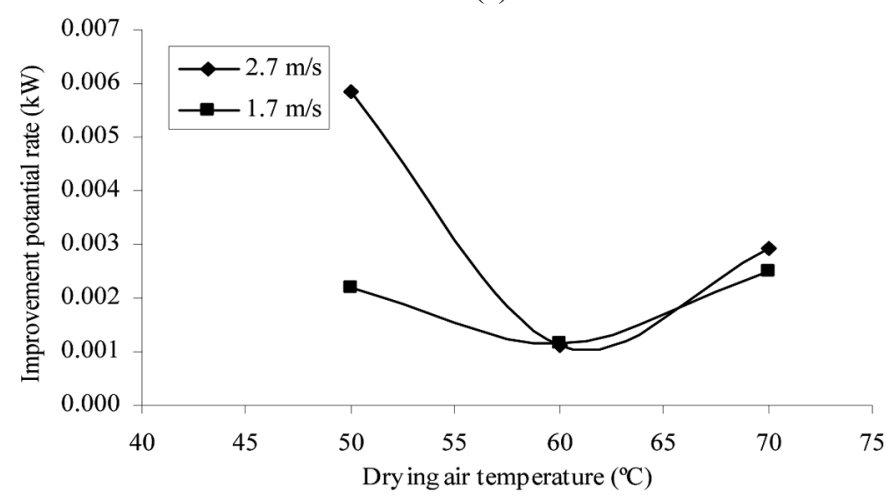

(b)

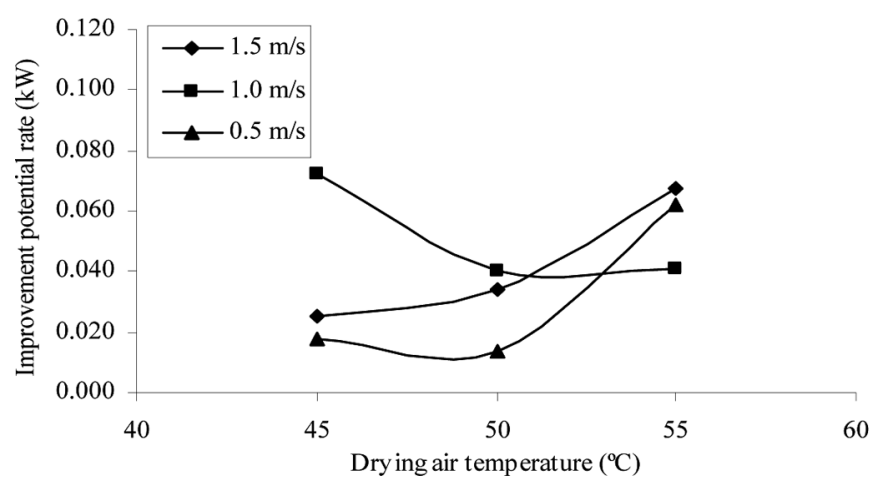

(c)

FIG. 6. The change of improvement potential rate value with drying temperature during drying of broccoli florets in three different systems: (a) tray dryer, (b) fluid bed, and (c) heat pump.

using Eq. (23a) were higher than those calculated by Eq. (23b) in some studies. It may be concluded that it was more meaningful, objective, and useful to assess the performance of the drying process relative to the performance of similar drying processes on the product (or benefit)/fuel basis.

Figure 5 shows the variation of the exergy destruction ratios depending on the drying air temperature and the velocity. Whereas the maximum exergy destruction rates were obtained at the drying air temperature of $55^{\circ} \mathrm{C}$ in the heat
TABLE 3

The results of exergy analyses using Eq. (23a): (a) Tray drier, (b) Fluid bed drier, and (c) Heat pump drier

\begin{tabular}{lcccc}
\hline $\mathrm{T}_{\mathrm{da}}\left({ }^{\circ} \mathrm{C}\right)$ & $\mathrm{V}(\mathrm{m} / \mathrm{s})$ & $(\dot{E} x)_{\text {in }}(\mathrm{kW})$ & $(\dot{E} x)_{\text {out }}(\mathrm{kW})$ & $\eta_{\text {ex }}(\%)$ \\
\hline & \multicolumn{4}{c}{ (a) } \\
50 & $1.5 \mathrm{~m} / \mathrm{s}$ & 0.226 & 0.180 & 79.60 \\
60 & $1.5 \mathrm{~m} / \mathrm{s}$ & 0.413 & 0.339 & 81.92 \\
70 & $1.5 \mathrm{~m} / \mathrm{s}$ & 0.722 & 0.553 & 76.54 \\
50 & $1.0 \mathrm{~m} / \mathrm{s}$ & 0.166 & 0.124 & 74.76 \\
60 & $1.0 \mathrm{~m} / \mathrm{s}$ & 0.278 & 0.217 & 78.11 \\
70 & $1.0 \mathrm{~m} / \mathrm{s}$ & 0.518 & 0.360 & 69.58 \\
50 & $0.5 \mathrm{~m} / \mathrm{s}$ & 0.091 & 0.054 & 59.70 \\
60 & $0.5 \mathrm{~m} / \mathrm{s}$ & 0.138 & 0.109 & 78.99 \\
70 & $0.5 \mathrm{~m} / \mathrm{s}$ & 0.250 & 0.179 & 71.55 \\
& & $(\mathrm{~b})$ & & \\
50 & $2.7 \mathrm{~m} / \mathrm{s}$ & 0.014 & 0.088 & 74.23 \\
60 & $2.7 \mathrm{~m} / \mathrm{s}$ & 0.008 & 0.134 & 90.86 \\
70 & $2.7 \mathrm{~m} / \mathrm{s}$ & 0.018 & 0.208 & 88.19 \\
50 & $1.7 \mathrm{~m} / \mathrm{s}$ & 0.051 & 0.040 & 79.22 \\
60 & $1.7 \mathrm{~m} / \mathrm{s}$ & 0.084 & 0.075 & 88.25 \\
70 & $1.7 \mathrm{~m} / \mathrm{s}$ & 0.136 & 0.118 & 86.49 \\
& & $(\mathrm{c})$ & & \\
45 & $1.5 \mathrm{~m} / \mathrm{s}$ & 1.961 & 1.739 & 88.66 \\
50 & $1.5 \mathrm{~m} / \mathrm{s}$ & 2.369 & 2.083 & 87.96 \\
55 & $1.5 \mathrm{~m} / \mathrm{s}$ & 2.911 & 2.469 & 84.81 \\
45 & $1.0 \mathrm{~m} / \mathrm{s}$ & 1.360 & 1.046 & 76.93 \\
50 & $1.0 \mathrm{~m} / \mathrm{s}$ & 1.778 & 1.511 & 85.00 \\
55 & $1.0 \mathrm{~m} / \mathrm{s}$ & 1.917 & 1.637 & 85.43 \\
45 & $0.5 \mathrm{~m} / \mathrm{s}$ & 0.716 & 0.604 & 84.34 \\
50 & $0.5 \mathrm{~m} / \mathrm{s}$ & 0.855 & 0.746 & 87.25 \\
55 & $0.5 \mathrm{~m} / \mathrm{s}$ & 1.037 & 0.784 & 75.59 \\
\hline
\end{tabular}

pump dryer, the minimum exergy destruction rates were at the drying air temperature of $60^{\circ} \mathrm{C}$ in the fluid bed dryer. Because the exergy efficiency was highest at $60^{\circ} \mathrm{C}$ for both velocities in the fluid bed dryer, the best drying temperature at the range studied could be concluded as $60^{\circ} \mathrm{C}$. Furthermore, lowest exergy destruction rate at this temperature presented the similar suggestion for fluid bed dryer (Fig. 5b). In general, the exergy destruction rate was decreased as the drying air velocity decreased in all drying systems, whereas it increased as the drying temperature increased in the heat pump dryer and tray dryer.

The variations of the improvement potential rates of the drying chambers with drying air temperature and velocity were similar to those of exergy destruction rates. Maximum improvement potential rate was predicted as $0.072 \mathrm{~kW}$ at the drying air temperature of $45^{\circ} \mathrm{C}$ and air velocity of $1 \mathrm{~m} / \mathrm{s}$ in the heat pump dryer. 


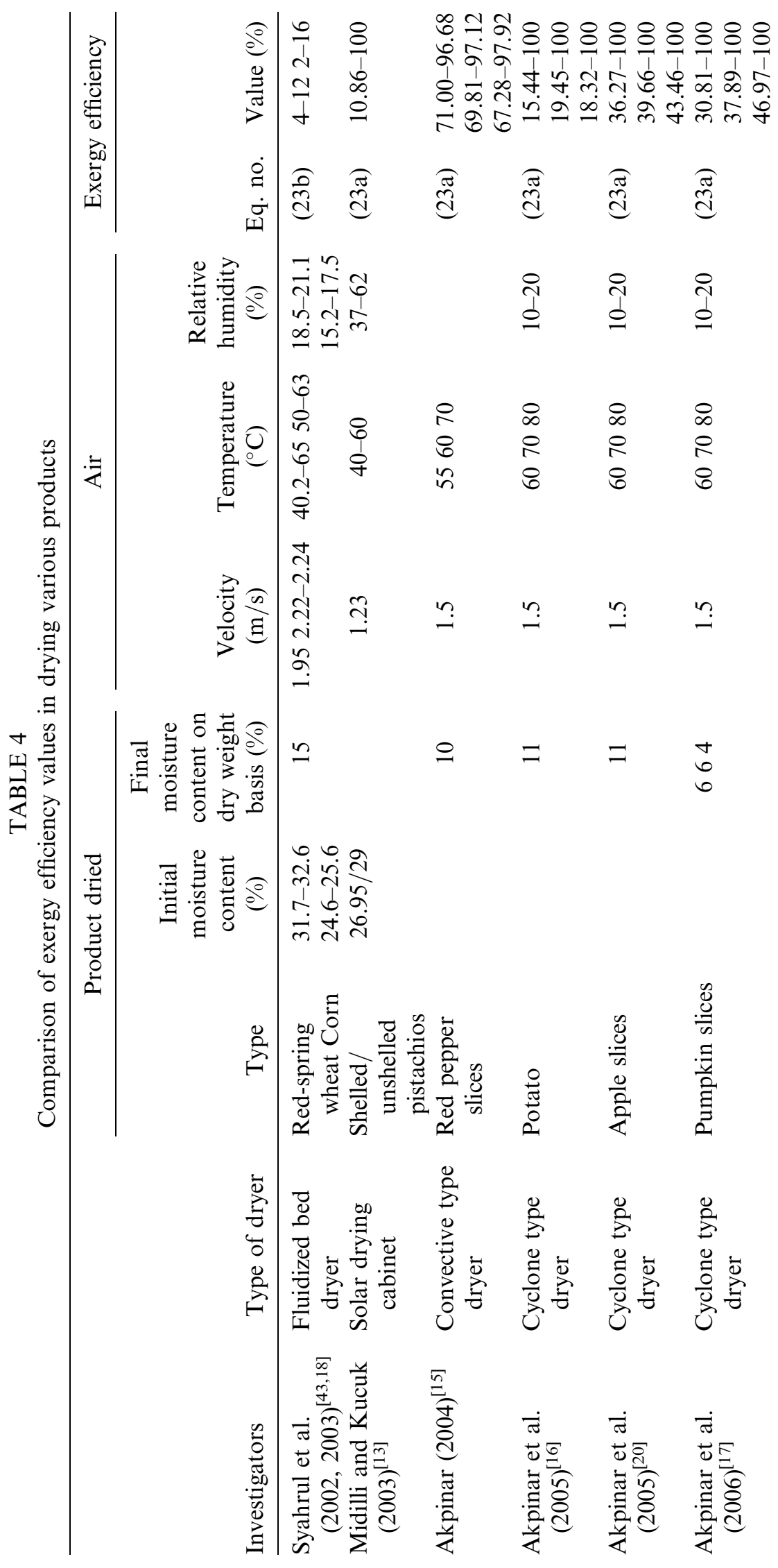




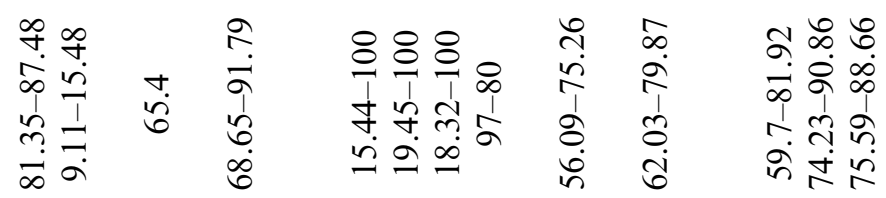

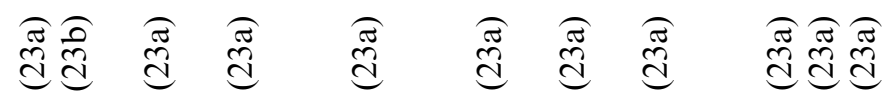

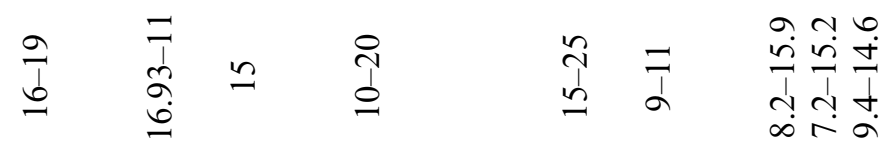

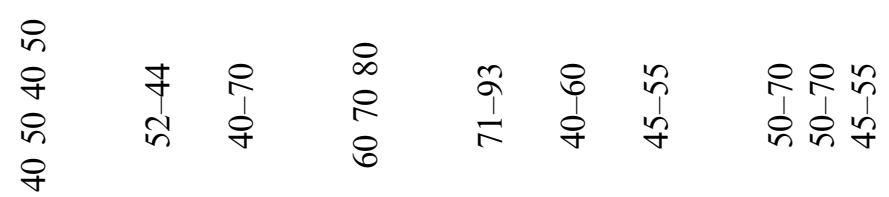

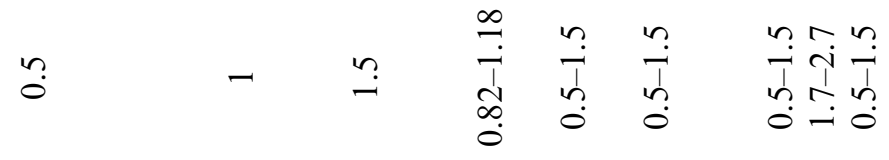

$\simeq \quad$ =

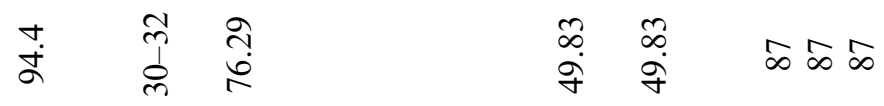

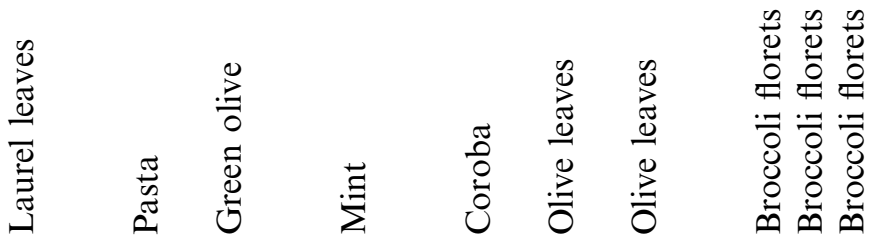

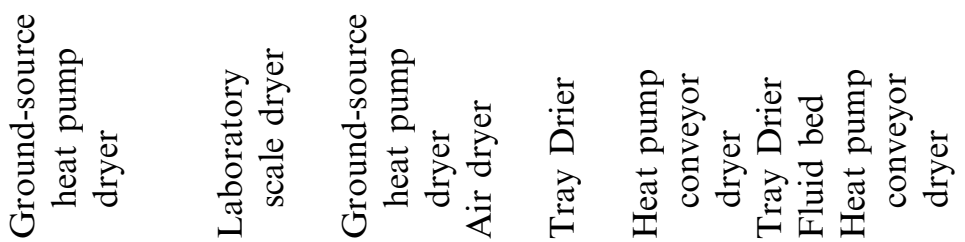

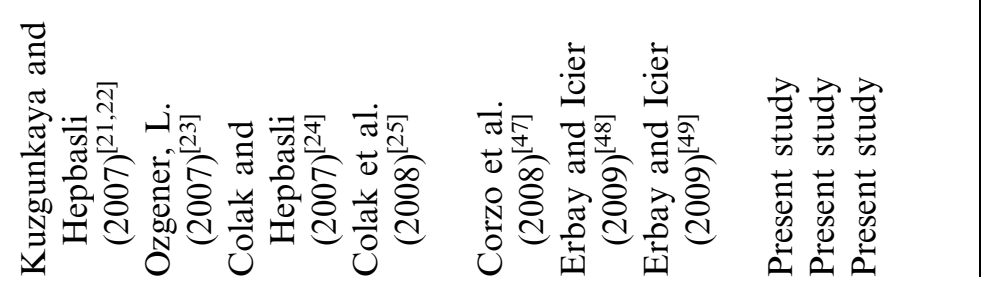


Because the heat pump dryer had higher capacity and overall energy input, its improvement potential values for $50^{\circ} \mathrm{C}$ were higher than those of other drying systems. On the other hand, it had adequately higher exergy efficiency values for the same temperature and air velocity values compared to other small-scale systems. This study presented that both exergy efficiency and the improvement potential approach were used as comparative performance variables for drying systems even if they had different capacities.

\section{CONCLUSION}

The experimental data obtained from the measurements were also utilized to perform a performance assessment of the drying process through exergy efficiencies, exergy destruction, and improvement potential. Some concluding remarks obtained from the present study are as follows:

- The exergy efficiency term found by the ratio of the product exergy to exergy inflow gave more meaningful and comparative results rather than the term defined on the product/fuel basis.

- In evaluating the performance of various types of drying systems using the exergy analysis method, the relations selected are of importance. The exergy efficiency of the drying chamber of tray dryer increased with the rise in air velocity.

- In the fluid bed dryer, the highest exergy efficiency value of the drying chamber was obtained at the drying air temperature of $60^{\circ} \mathrm{C}$ and air velocity of $2.7 \mathrm{~m} / \mathrm{s}$.

- In the heat pump dryer, the exergy efficiency of the drying chamber decreased as the drying air temperature increased, whereas it increased as the air velocity increased.

- According to the comparison of exergy efficiencies of dryers during drying of broccoli florets, the most efficient dryer was determined as fluid bed dryer with higher exergy efficiencies and lower improvement potentials.

- Performance analysis for different drying processes can be made by using the improvement potential term even if drying systems have different capacities.

\section{NOMENCLATURE}

$C \quad$ Specific heat $\left(\mathrm{kJ} \mathrm{kg}^{-1} \mathrm{~K}^{-1}\right)$

$\dot{E} \quad$ Rate of net energy transfer $\left(\mathrm{kJ} \mathrm{s}^{-1}\right)$

$\dot{E} x \quad$ Exergy rate $\left(\mathrm{kJ} \mathrm{s}^{-1}\right)$

$F \quad$ Function

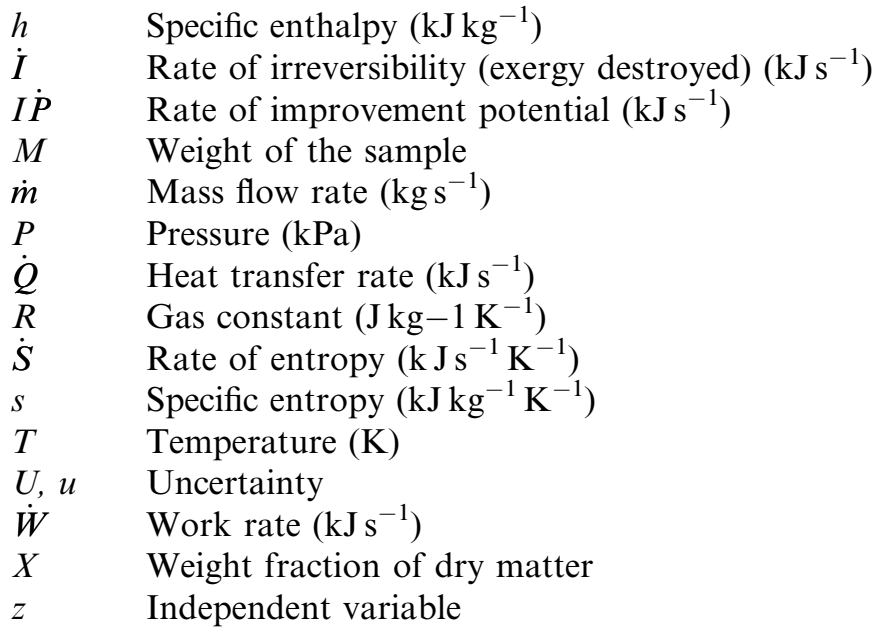

\section{Greek Symbols}

$\eta \quad$ Exergy efficiency

$\psi \quad$ Flow (or specific) exergy $\left(\mathrm{kJ} \mathrm{kg}^{-1}\right)$

$\omega \quad$ Specific humidity $\left(\mathrm{g} \mathrm{g}^{-1}\right)$

\section{Subscripts}

$0 \quad$ Restricted dead state

a Air

$D \quad$ Destroyed, destruction

$d a \quad$ Drying air

$e \quad$ At equilibrium

evap Evaporation

ex Exergetic, exergy

da Drying air

gen Generation

in Inlet

initial Initial

$L \quad$ Loss

$m \quad$ Food material

out Outlet

$s \quad$ Surface

sat@T Saturated

$t \quad$ At time $t$

$v \quad$ Vapor

w Water

\section{ACKNOWLEDGMENTS}

The authors are grateful for the financial support provided for the project entitled "Design, Test and Performance Evaluation of a Gas Engine-Driven Solar Assisted Band Conveyor Heat Pump Drying System" under project no: 106M482 by the Scientific and Technological Research Council of Turkey (TUBITAK). They also are grateful for the valuable comments of the reviewers and editor, which have been utilized to increase the quality of the paper. 


\section{REFERENCES}

1. Gunhan, T.; Demir, V.; Hancioglu, E.; Hepbasli, A. Mathematical modelling of drying of bay leaves. Energy Conversion and Management 2005, 46, 1667-1679.

2. Yu-Ting Chen, Y.; Long-Fang, O.; Chen, J.-F.S. Senescenceassociated genes in harvested broccoli florets. Plant Science 2008, $175,137-144$.

3. Haristoy, X.; Duprez, K.A.; Duprez, A.; Lozniewskil, A. Efficacy of sulforaphane in eradicating Helicobacter pylori in human gastric xenografts implanted in nude mice. Antimicrobial Agents in Chemotherapy 2003, 47, 3982-3984.

4. Barta, I.; Smerak, P.; Polivkova, Z.; Sestakova, H.; Langova, M.; Turek, B.; Bartova, J. Current trends and perspectives in nutrition and cancer prevention. Neoplasma 2006, 53, 19-25.

5. Mandelova, L.; Totusek, J. Broccoli juice treated by high pressure: Chemoprotective effects of sulforaphane and indole-3-carbinol. International Journal of High Pressure Research 2007, 27, 151-156.

6. Fahey, J.W.; Zhang, Y.; Talalya, P. Broccoli sprouts: An exceptionally rich source of inducers of enzymes that protect against chemical carcinogens. Proceedings of the National Academy of Sciences 1997, 94, 10367-10372.

7. Murillo, G.; Mehta, R.G. Cruciferous vegetables and cancer prevention. Nutrition and Cancer 2001, 41, 17-28.

8. Bon, J.; Simal, S.; Rossello, C.; Mulet, A. Drying characteristics of hemispherical solids. Journal of Food Engineering 1997, 34, 109-122.

9. Simal, S.; Rossell, C.; Berna, A.; Mulet, A. Drying of shrinking cylinder-shaped bodies. Journal of Food Engineering 1998, 37, 423-435.

10. Mulet, A.; Sanjúan, N.; Bon, J.; Simal, S. Drying model for highly porous hemispherical bodies. European Food Research and Technology 1999, 210, 80-83.

11. Sanjuan, N.; Clemente, G.; Bon, J.; Mulet, A. The effect of blanching on the quality of dehydrated broccoli florets. European Food Research and Technology 2001, 213, 474-479.

12. Mrkic, V.; Ukrainczyk, M.; Tripalo, B. Applicability of moisture transfer Bi-Di correlation for convective drying of broccoli. Journal of Food Engineering 2007, 79, 640-646.

13. Midilli, A.; Kucuk, H. Energy and exergy analysis of solar drying process of pistachio. Energy 2003, 28, 539-556.

14. Dincer, I.; Sahin, A.Z. A new model for thermodynamic analysis of a drying process. International Journal of Heat and Mass Transfer 2004, 47, 645-652.

15. Akpinar, EK. Energy and exergy analyses of drying of red pepper slices in a convective type dryer. International Communications in Heat and Mass Transfer 2004, 31 (8), 1165-1176.

16. Akpinar, E.K.; Midilli, A.; Bicer, Y. Energy and exergy of potato drying process via cyclone type dryer. Energy Conversion and Management 2005, 46 (15-16), 2530-2552.

17. Akpinar, E.K.; Midilli, A.; Bicer, Y. The first and second law analyses of thermodynamic of pumpkin drying process. Journal of Food Engineering 2006, 72 (4), 320-331.

18. Syahrul, S.; Dincer, I.; Hamdullahpur, F. Thermodynamic modeling of fluidized bed drying of moist particles. International Journal of Thermal Sciences 2003, 42, 691-701.

19. Aghbashlo, M.; Kianmehr, M.H.; Arabhosseini, A. Energy and exergy analyses of thin-layer drying of potato slices in a semiindustrial continuous band dryer. Drying Technology 2008, 26, 1501-1508.

20. Akpinar, E.K.; Midilli, A.; Bicer, Y. Thermodynamic analysis of the apple drying process. Proceedings of the IMechE Part E: Journal of Process Mechanical Engineering 2005, 219, 1-14.

21. Kuzgunkaya, E.H.; Hepbasli, A. Exergetic performance assessment of a ground source heat pump drying system. International Journal of Energy Research 2007, 31, 760-777.
22. Kuzgunkaya, E.H.; Hepbasli, A. Exergetic evaluation of drying of laurel leaves in a vertical ground-source heat pump drying cabinet. International Journal of Energy Research 2007, 31, 245-258.

23. Ozgener, L. Exergoeconomic analysis of small industrial pasta drying systems. Proceedings of the Institution of Mechanical Engineers Part A - Journal of Power and Energy 2007, 221, 899-906.

24. Colak, N.; Hepbasli, A. Performance analysis of drying of green olive in a tray dryer. Journal of Food Engineering 2007, 20, 1188-1193.

25. Colak, N.; Kuzgunkaya, E.; Hepbasli, A. Exergetic assessment of drying of mint leaves in a heat pump dryer. Journal of Food Engineering 2008, 31, 281-298.

26. Ozgener, L.; Ozgener, O. Exergy analysis of drying process: An experimental study in solar greenhouse. Drying Technology 2009, 27 (4), 580-586.

27. Bruttini, R.; Crosser, O.K.; Liapis, A.I. Exergy analysis for the freezing stage of the freeze drying process. Drying Technology 2001, 19 (9), 2303-2313.

28. Mujumdar, A.S. A review of exergy method-Technical and ecological applications. Drying Technology 2005, 23 (12), 2523-2524.

29. Radivoje, T. Mathematical model for exergy analysis for drying plants. Drying Technology: An International Journal 1995, 13 (1), 437-445.

30. Szargut, J.; Morris, D.R.; Stewart, F.R. Exergy Analysis of Thermal, Chemical and Metallurgical Processes; Taylor \& Francis: New York, 1988.

31. Dincer, I. On energetic, exergetic and environmental aspects of drying systems. International Journal of Energy Research 2002, 26, 717-727.

32. AOAC. Dry matter content. In Official Methods of Analysis of the Association of Official Analytical Chemists, 15th Ed; Helrich, K., Ed.; Association of Official Analytical Chemists: Arlington, VA, 1990.

33. International Union of Pure and Applied Chemistry. In Standard Methods for the Analysis of Oils, Fats and Derivatives, 7th Ed; Paquot, C.; Hautfenne, A., Eds.; Blackwell Publications: Oxford, England, 1987.

34. AOAC. Nitrogen in spices. In Official Methods of Analysis of the Association of Official Analytical Chemists, 16th Ed; Helrich, K. Ed.; Association of Official Analytical Chemists: Arlington, VA, 1995.

35. AOAC. Ash of canned vegetables. In Official Methods of Analysis of the Association of Official Analytical Chemists, 16th Ed; Helrich, K. Ed.; Association of Official Analytical Chemists: Arlington, VA, 1995.

36. Anonymous. TS ISO 15598. Tea-Determination of Crude Fiber Content; Turkish Standards Institute: Ankara, 2003.

37. Akpinar, E.K.; Bicer, Y.; Midilli, A. Modelling and experimental study on drying of apple slices in a convective cyclone dryer. Journal of Food Process Engineering 2003, 26, 515-541.

38. Holman, J.P. Analysis of experimental data. In Experimental Methods for Engineers, 7th Ed; Holman, J.P., Ed.; McGraw Hill: Singapore, $2001 ; 48-143$.

39. Kotas, T.J. The Exergy Method of Thermal Plant Analysis; Anchor Brendon: Tiptree, Essex, 1985.

40. Hepbasli, A.; Akdemir, O. Energy and exergy analysis of a ground source (geothermal) heat pump system. Energy Conversion and Management 2004, 45, 737-753.

41. Rosen, M.A.; Dincer, I. Effect of varying dead-state properties on energy and exergy analyses of thermal systems. International Journal of Thermal Sciences 2004, 43, 121-133.

42. Van Gool, W. Energy policy: Fairly tales and factualities. In Innovation and Technology Strategies and Policies, Soares O.D.D., de Cruz, A.M., Pereira, G.C., Soares I.M.R.T., Reis, A.J.P.S., Eds.; Kluwer: Dordrecht; 1997; pp. 93-105.

43. Hammond, G.P.; Stapleton, A.J. Exergy analysis of the United Kingdom energy system. Proceedings of the Institution of Mechanical Engineers 2001, 215 (2), 141-162.

44. Rahman, S. Food Properties Handbook; CRC Press: Boca Raton, FL, USA, 1995; 225-271. 
45. Syahrul, S.; Hamdullahpur, F.; Dincer, I. Exergy analysis of fluidized bed drying of moist particles. Exergy, an International Journal 2002, 2, 87-98.

46. Anonymous. F-Chart Software Engineering Equation Solver (EES), Version 8.156D; Madison, WI, 2008.

47. Corzo, O.; Bracho, N.; Vásquez, A.; Pereira, A. Energy and exergy analyses of thin layer drying of coroba slices. Journal of Food Engineering 2008, 86, 151-161.
48. Erbay, Z.; Icier, F. Optimization of hot air drying of olive leaves using response surface methodology. Journal of Food Engineering 2009, 91 (4), 533-541.

49. Erbay, Z.; Icier, F. Optimization of drying of olive leaves in a pilot scale heat pump dryer. Drying Technology 2009, 27 (3), 416-427. 